\title{
Factors Affecting Rural Youth Interest in Agriculture in Probolinggo District Indonesia
}

\author{
Jabal Tarik Ibrahim $^{1 *}$, M. Zul Mazwan ${ }^{2}$, Fithri Mufriantie ${ }^{3}$ \\ ${ }^{1,2}$ Department of Agribusiness, University of Muhammadiyah Malang, East Java, Indonesia \\ ${ }^{3}$ Department of Agribusiness, University of Muhammadiyah Bengkulu, Bengkulu, Indonesia
}

\author{
*Corresponding Author: Jabal Tarik Ibrahim, Department of Agribusiness, University of \\ Muhammadiyah Malang, East Java, Indonesia
}

\begin{abstract}
The proportion of farmer households to the total number of households has tended to decline over the past 10 years. This decline illustrates that the agricultural sector is less desirable as a source of livelihood, especially for the younger generation. The decline in the performance of farmers and the decrease in the productivity of agricultural land will further complicate food security, especially food availability. The purpose of this study was to analyze the influence of interest on rural youth participation in agricultural activities. The research method used is a survey research method with explanatory research type. The research location was carried out purposively in Triwungan Village, Kotaanyar District, Probolinggo Regency, East Java Province, Indonesia. The sample used was 50 rural youth. The analytical method used is Partial Least Square (PLS). The results showed that the R-square model value was 0.58. Factors that influence the interest of rural youth in farming are prestige, future security, and parental land area. While the privilege factor, parental encouragement, education level, education suitability, commodity value and income did not significantly influence the interest of rural youth to farm.
\end{abstract}

Keywords: Rural Youth, Interest, Agriculture, PLS

\section{INTRODUCTION}

The proportion of farmer households (RTP) to the total number of households has tended to decline during the last 10 years. The decline in agricultural households indicates that there is a proportionate decrease in the number of farmers and farm laborers. According to Kvartiuk et al. (2020); Swarts and Aliber (2013), stated that urbanization and aging rural populations contribute to skilled workers in agriculture worldwide. This decline illustrates the less interest in the agricultural sector as a place of livelihood. The decline in farmer households when followed by a decline in farmer performance and a decrease in agricultural land productivity will further complicate food security, especially food availability. In developing countries, youth are targeted in implementing a combination of agricultural values, technology, and entrepreneurship that will have a good impact on the strength of food security (Ripoll et al., 2017; Larsen and Lilleør, 2014). The element of food availability is one of the pillars of food security in addition to food distribution and food consumption / absorption. The decline in food security will be a contributor to a weak point in national resilience. Based on the report of the People's Coalition for Food Sovereignty, interest in becoming a farmer among youth is decreasing.

There are several variables that influence parents to encourage their children to become farmers, among them is land ownership. Bezu and Holden (2014) stated that the majority of parents recognize that their farming is the main access for their children and believe that they need to inherit at least part of their land before they die. Other variables such as the commodity types (Sharma, 2007), crop sales pattern, net income (Kvartiuk et al., 2020), and the ability of parents to teach farming techniques to their children. According to (Onemolease and Alakpa, 2009), rural youth who obtain materials from agricultural extension agents have a greater chance of adopting plant technology. Apart from these variables, a youth also has social factors (Kvartiuk et al., 2020), level of education, economic (Kumar, 2010), psychology, and culture (Katie D. Ricketts, 2019; Inegbedion and Islam, 2020) that influenced his interest in becoming a farmer. Work environment factors also influence youth interest in becoming farmers. The condition of the industrial sector which does not absorb much labor will still encourage some youth to work in the agricultural sector. 
Despite the decreasing interest of rural youth in agriculture, regeneration remains an important matter and needs to be prioritized in national, regional and local district policies, even in local villages. To design farmer regeneration at the national level, research on farmer regeneration among the millennial generation is important. The purpose of this study was to analyze the influence of interest on rural youth participation in agricultural activities.

\section{METHOD}

This research is a type of explanatory research. The research method used in general is the survey method. The research location was carried out purposively in Triwungan Village, Kotaanyar District, Probolinggo Regency, East Java Province. The consideration of choosing the research location was based on the location of the village which still had an agricultural nuance around the industrial area of the Paiton Steam Power Plant Industry Unit one to unit four. The number of samples was obtained based on the diversity in the research location. At least the number of respondents is at least 50 youth. Based on this data, the researchers generalized the millennial youth population in the study area. Most of the research data is primary data collected by interview using a questionnaire that has been prepared previously.

The various needs of millennial rural youth were identified with open questions. Meanwhile, questions related to interest and participation used a likert scale with a score. Interest, participation, social and economic variables data are ordinal scale data. Partial Least Square (PLS) is used to explain the influence of the social and economic variables of millennial rural youth on interest and participation in agricultural activities.

\section{a. Outer Model}

Outer Model describes the relationship between latent variables and their manifest variables (indicators). In the outer model, there are two types of models, namely the formative indicator model and the reflexive indicator model. The reflexive model occurs when the manifest variable is influenced by latent variables, while the formative model assumes that the manifest variable affects the latent variable with the direction of causality flowing from the manifest variable to the latent variable. The following is the PLS equation in this study:

1) Exogenous Latent Variables $X 1$ (prestige as a farmer)

$X_{1.1}=\lambda_{X 1.1} \xi_{1}+\delta_{1.1}$ (the same honor as other jobs in terms of profession)

$X_{1.2}=\lambda_{X 1.2} \xi_{1}+\delta_{1.2}$ (the same honor as other jobs in the selection of a prospective life partner)

2) Exogenous Latent Variables $X 2$ (privilege as a farmer)

$X_{2.1}=\lambda_{X 2.1} \xi_{2}+\delta_{2.1}$ (government service)

$X_{2.2}=\lambda_{X 2.2} \xi_{2}+\delta_{2.2}$ (privilege as other jobs in terms of profession)

3) Exogenous Latent Variables $X 3$ (parental encouragement)

$X_{3.1}=\lambda_{X 3.1} \xi_{3}+\delta_{3.1}$ (parental encouragement)

4) Exogenous Latent Variables $X 4$ (future guarantee)

$X_{4.1}=\lambda_{X 4.1} \xi_{4}+\delta_{4.1}$ (life guarantee

$X_{4.2}=\lambda_{X 4.2} \xi_{4}+\delta_{4.2}$ (future guarantee)

5) Exogenous Latent Variables $X 5$ (level of education)

$X_{5.1}=\lambda_{X 5.1} \xi_{5}+\delta_{5.1}$ (level of education)

6) Exogenous Latent Variables X6 (suitability of education)

$X_{6.1}=\lambda_{X 6.1} \xi_{6}+\delta_{6.1}$ (suitability of education)

$X_{6.2}=\lambda_{X 6.2} \xi_{6}+\delta_{6.2}$ (suitability of skill)

7) Exogenous Latent Variables $X 7$ (parental land area)

$X_{7.1}=\lambda_{X 7.1} \xi_{7}+\delta_{7.1}$ (parental land area) 
8) Exogenous Latent Variables X8 (commodity value)

$$
\begin{aligned}
& X_{8.1}=\lambda_{X 8.1} \xi_{8}+\delta_{8.1} \text { (commodity types) } \\
& X_{8.2}=\lambda_{X 8.2} \xi_{8}+\delta_{8.2} \text { (economic value) }
\end{aligned}
$$

9) Exogenous Latent Variables $X 9$ (income)

$$
\begin{aligned}
& X_{9.1}=\lambda_{X 9.1} \xi_{9}+\delta_{9.1} \text { (sufficiency) } \\
& X_{9.2}=\lambda_{X 9.2} \xi_{9}+\delta_{9.2} \text { (proper job) }
\end{aligned}
$$

The symbol in the outer model equation above has meaning; variables $\mathrm{X}$ and $\mathrm{Y}$ are manifest variables for exogenous latent variable $(\xi)$ and endogenous latent variable $(\eta)$. In addition, there is $\lambda$ which is the outer loading value which shows the simple regression coefficient between the indicator / manifest variable and the latent variable. Not only that, in the outer model equation there is also a measurement error (noise) shown by the variables $\delta$ for exogenous and $\varepsilon$ for endogenous.

\section{b. Inner Model}

The structural model or inner model describes the relationship model between latent variables which is formed based on the substance of the theory. The general equation for the PLS structural model in this study is as follows:

$$
\eta=\gamma_{1} \xi_{1}+\gamma_{2} \xi_{2}+\gamma_{3} \xi_{3}+\gamma_{4} \xi_{4}+\gamma_{5} \xi_{5}+\gamma_{6} \xi_{6}+\gamma_{7} \xi_{7}+\varsigma_{1}
$$

where,

$\gamma_{1}=$ interest of tillage

$\gamma_{2}=$ interest of planting

$\gamma_{3}=$ interest of pest and disease control

$\gamma_{4}=$ interest of weeds control

$\gamma_{5}=$ interest of harvesting

$\gamma_{6}=$ interest of processing of agricultural products

$\gamma_{7}=$ interest of modern equipment

The inner model equation is written with the symbols $\gamma, \beta$, and $\zeta$. The variable $\gamma$ is the path coefficient / relationship between endogenous latent variables and exogenous latent variables. The variable $\beta$ differs from the variable $\gamma$, where this variable is the path coefficient between endogenous latent variables and other endogenous latent variables. Besides that, there is a residual variable which is denoted by $\zeta$.

c. Evaluation of PLS Model

1) Composite Reliability ( $\rho c)$

The Composite Reliability $(\rho c)$ value is used to measure the consistency of the indicator block. It is recommended that the Composite Reliability ( $\rho c$ ) value is greater than 0.6. Composite Reliability ( $\rho c)$ can be calculated with the following formula.

\section{2) Convergent Validity}

$$
\rho \mathrm{c}=\frac{\left(\sum k \lambda j k\right)^{2}}{\left(\sum k \lambda j k\right)^{2}+\sum k \operatorname{var}(\zeta j k)}
$$

Convergent validity is seen based on the correlation between the item / indicator scores with the construct score. An individual reflective measure is said to be high if it correlates more than 0.7 with the construct to be measured.

3) Discriminant Validity

The discriminant validity of indicators can be seen in the cross-loading between the indicators and their constructs. If the correlation of the constructs with the indicator is greater than the size of the other constructs, it means that the latent constructs predict the size of their block better than other block sizes. 
4) Evaluation of Structural Model (Inner Model)

Quality of Structural Model evaluated by measuring index test, $\mathrm{R}^{2}$.

5) Hypothesis Test

The statistical hypothesis for the outer model is as follows:

$$
\begin{aligned}
& \mathrm{H}_{0}: \lambda_{i}=0 \text { (indicator to }-i \text { insignificant) } \\
& \mathrm{H}_{0}: \lambda_{i} \neq 0 \text { (indicator to }-i \text { significant) }
\end{aligned}
$$

The statistical hypothesis for the inner model is as follows:

$$
\begin{aligned}
& \mathrm{H}_{0}: \gamma_{i}=0 \text { (indicator to }-i \text { insignificant) } \\
& \mathrm{H}_{0}: \gamma_{i} \neq 0 \text { (indicator to }-i \text { significant) }
\end{aligned}
$$

The test statistic used is the $\mathrm{t}$ test, with the following formula.

$$
t=\frac{\lambda j k}{S E(\lambda j k)} \quad t=\frac{\beta \mathrm{i}}{S E(\beta \mathrm{i})}
$$

With $\mathrm{t}$ is the $\mathrm{t}$-count and $\mathrm{SE}(\beta \mathrm{g})$ is the standard error obtained from bootstrapping, when the size of the empirical $t$ value is $>1.96$, it is assumed that the path coefficient is significantly different at the $5 \%$ significance level ( $\alpha=0,05$ 2-way test).

\section{FINDINGS / DISCUSSIONS}

\section{a. Outer Model}

Evaluation of the outer model is done through 3 criteria, namely convergent validity, discriminant validity and composite reliability.

1) Composite Reliability

Tabel1. Uji Realibilitas pada Outer Model

\begin{tabular}{|c|c|c|c|}
\hline Variabel & Cronbach's Alpha & Composite Reliability & Keterangan \\
\hline X1 & 0.586 & 0.828 & Reliabel \\
\hline X2 & 0.473 & 0.792 & Reliabel \\
\hline X3 & 1.000 & 1.000 & Reliabel \\
\hline X4 & 0.657 & 0.853 & Reliabel \\
\hline X5 & 1.000 & 1.000 & Reliabel \\
\hline X6 & -0.064 & 0.753 & Reliabel \\
\hline X7 & 1.000 & 1.000 & Reliabel \\
\hline X8 & -0.974 & 0.503 & Reliabel \\
\hline X9 & 0.477 & 0.793 & Reliabel \\
\hline Y & 0.842 & 0.881 & \\
\hline
\end{tabular}

Sumber: Output of Wrap PLS 6.0, diolah 2020

Based on Table 1, the Composite Reliability value on all blocks has met the Composite Reliability assumption, which is greater than 0.7 for each latent and has high consistency.

2) Convergent Validity

The outer loadings output has met the convergent validity assumption. The result of data analysis shows that all indicators has met the criteria of convergent validity with p-value of $<0,001(<0,05)$ for all indicators.

3) Discriminant Validity

Based on the cross loading table above, it can be seen that for each indicator of each latent variable, it has the largest loading factor value compared to other loading factor variables if served with other variables. This means that each latent variable already has good discriminant validity where the discriminant validity requirements in this study have been fulfilled. 


\section{b. Inner Model}



Fig1. Structural Model PLS

Source: Output of Wrap PLS 6.0, 2020

Based on analysis, it can be concluded that the R-square value of 9 factors, namely X1 (prestige), X2 (privilege), X3 (parental encouragement), X4 (future guarantee), X5 (education level), X6 (educational suitability), X7 (parental land area), X8 (commodity value), X9 (income) to the $\mathrm{Y}$ variable (interest in becoming a farmer) is 0.58 . With this $\mathrm{R}$-square value, it is known that $58 \%$ of the interest variable of rural youth to become farmers can be explained well by the variables of prestige, privilege, parental encouragement, future guarantee, education level, educational suitability, parental land area, commodity value and income. while the other $42 \%$ are influenced by other variables outside the model.

Table2. Hypothesis Testing Using P Value

\begin{tabular}{|c|c|c|c|}
\hline Hipotesis & Path Coefficient & P Value & Explanation \\
\hline X1 -> Y & 0.307 & 0.009 & Significant \\
\hline X2 -> Y & 0.042 & 0.380 & Insignificant \\
\hline X3 -> Y & 0.026 & 0.425 & Insignificant \\
\hline X4 -> Y & 0.372 & 0.002 & Significant \\
\hline X5 -> Y & -0.124 & 0.178 & Insignificant \\
\hline X6 -> Y & -0.008 & 0.477 & Significant \\
\hline X7 -> Y & -0.356 & 0.003 & Insignificant \\
\hline X8 -> Y & -0.152 & 0.129 & Insignificant \\
\hline X9 -> Y & 0.143 & 0.143 & \\
\hline
\end{tabular}

where $\alpha=5 \%$

Source: Output of Wrap PLS 6.0, diolah 2020

Table 2 shows that the factors influence the interest of rural youth in farming are prestige (X1), future guarantee (X2) and parental land area (X3). While the variables of privilege variable (X2), parental encouragement (X3), education level (X5), suitability of education (X6), commodity value (X8) and income (X9) did not have a significant effect on the interest of rural youth youth to farm (Y). Each has a significance value of 0.380 or $38 \%$ (X2), 0.425 or $42.5 \%$ (X3), 0.178 or $42.5 \%$ (X5), 0.477 or $42.5 \%$ (X6), 0.129 or $42.5 \%$ (X8) and 0.143 or $42.5 \%$ (X9). Thus the hypothesis is rejected, so that the latent variables do not have a significant effect on the variable interest of rural youth to farm. High way of thinking or perception by rural youth that having proffesion in the agricultural sector is a guarantee for their tenure. So that high or low levels of education do not affect the field of work that will be pursued later. For rural youth, farming is also able to fulfill their needs regardless of the level and suitability of education.

The prestige variable measured through the indicators X1.1 (the same honor as other jobs in terms of profession) and X1.2 (the same honor as other jobs in the selection of a prospective life partner) has a significant effect on the interest of rural youth for farming with a significance value of 0.009 or $0.9 \%$. 
The coefficient value shows a positive value of 0.307 . This value shows that the prestige variable (X1) has a positive and significant effect on the variable of rural youth interest in farming (Y). This means that the more prestigious the farmer's job is, the more rural youth are interested in farming. These results are consistent with research conducted by Khatir and Rezaei-Moghaddam (2014) that rural youth who have access to the same facilities in all professions will have access to extension activities, access to agricultural knowledge, and household comfort. thus, the greater the capacity and capability of youth in agriculture and sustainable rural development. (Webster and Ganpat, 2014) confirmed that youth (78.3\%) expressed a desire to pursue a career in food production within the next five years. provide them with training and information on how to access resources, provide social services, and modernize the methods and techniques used for information dissemination to meet the needs of young people.

The variable of future guarantee which is measured as an indicator of X4.1 (life guarantee) and X4.2 (future guarantee) has a significant effect on the interest of rural youth to farm with a significance value of 0.002 or $0.2 \%$. The coefficient value shows a positive value of 0.372 which shows that the influence of the future guarantee variable (X4) on the variable of rural youth interest in farming (Y) is positive. That means, in this study, the future guarantee variable (X4) with its indicators has a positive effect on the latent variable of rural youth interest to become farmers (Y) with its indicators. If being a farmer has a great guarantee for the future, the farmers are increasingly interested in farming. This is due to the quite high level of youth desire in the Triwungan Village, Probolinggo Regency to fulfill physiological needs (clothing, food, and dwelling). Also in fulfilling the need for security (McCullagh, Yang and Cohen, 2020), social needs, appreciation needs and self-actualization needs (Che, Strang and Vajjhala, 2020). By cultivating high-value crops rural youth get a better life guarantee and will revive the interest of rural youth in farming (Sharma, 2007). This could be due to the limited options available to the rural poor. These findings are in line with Metelerkamp, Drimie and Biggs (2019) who emphasized that young people who choose to enter the agricultural sector in a position of structural conflict which is embarrassing and contrary to their inner feelings, can be called "forced labor". Especially when agriculture is the dominant activity in the economy in the region (Kumar, 2010; Kidido, Bugri and Kasanga, 2017). The structural transformation of population and employment in East Java Province is still in the primary sector or the agricultural sector (Ibrahim and Mazwan, 2020).

The variable of parental land area measured as an indicator of X7.1 (parental land area) has a significant influence on the interest of rural youth to farm with a significance value of 0.003 or $42.5 \%$. The coefficient value shows value of -0.356 which shows that the influence of the parental land area variable $(\mathrm{X} 7)$ on the variable of rural youth interest in farming (Y) is negative. Based on these results, the variable of parental land area (X7) with its indicators has a negative effect on the latent variable of rural youth interest in farming $(\mathrm{Y})$ with its indicators. The narrower the land owned by their parents, the more interested and motivated village youth are to farm. The narrow land owned by the respondent was due to the inheritance system by dividing the land among their children. So the determining factor for youth interest in farming is parents who leave land to their children through the distribution of inherited land. These results are in line with Kidido and Bugri (2020) adam argues that this narrow land tenure is a manifestation of the challenges underlying rural youth access to land under the customary system. This is also because land ownership by farmers in Indonesia is less than 1 hectare, the most important thing for them is that the land can be used for farming. According to Andersson Djurfeldt et al. (2019), for youth living with landless parents, they are effectively prohibited from engaging in the intensification process other than as labor. Bezu and Holden (2014) added that in developing countries, owning agricultural land is the most important factor determining whether rural residents can depend on the agricultural sector. (Kidido, Bugri and Kasanga, 2017) emphasized that youth's access to agricultural land is very important in exploiting their potential to increase agricultural production. Limited land permits and leases will reduce the ability of rural youth to make long-term investments and participate in commercial crop cultivation. Other findings are consistent with the research conducted by Bezu and Holden (2014) that the choice of youth from households with small land to agriculture is greater than that of youth who are raised from households with large tracts of land. Because parents who own large areas of land are able to provide access to higher education for their children so that their children get better paying jobs. 
The youth of Triwungan village in Probolinggo Regency have the motivation that agriculture is a job that has a guarantee for a good future, and sees agriculture as prestige with modern innovation and technology. If respondents have used technology and smartphones, it makes it easy for them to find various information including agriculture, so that making it easier for youth to earn more income. Technology and information not only make youth familiar with conventional farming but also organic farming and modern farming. Since youth have a tendency to acquire greater knowledge, they are eager to discover new ideas or discoveries (Cheteni, 2016). An extensive and intensive training program should be emphasized for rural youth regarding integrated agricultural systems, integrated pest and disease management and technology for soil and water conservation as well as nursery management, production, nursery management, leadership and group dynamics. Betcherman asnd Khan (2018); Katie D. Ricketts (2019); Leonard, Okoro and Imo (2020) added that the stability of investment and entrepreneurship in agriculture will motivate rural youth to work in agriculture. This will also improve the welfare of rural youth (Arslan et al., 2020). Government policies also need to be more holistic and systematic in supporting the development of agribusiness entrepreneurs and entrepreneurial opportunities for agricultural graduates (Inegbedion and Islam, 2020).

In addition, family environmental factors have an impact on the interest of rural youth to farm. The motivation and values shared by family members are essential to their success. This support can take many forms, such as financial, moral, and motivational support. Many parents talk about the values, work ethic, and discipline instilled in them from an early age (Katie D. Ricketts, 2019). Auta, Abdullahi and Nasiru (2010) revealed that the role of interpersonal communication between rural youth (especially friends) is very important in facilitating the flow of agricultural information. This is because farmers learn faster from fellow farmers. According to Yeboah et al. (2020), family and broader social relationships are key for youth to access the resources needed in the form of land, capital and inputs to start their businesses.

\section{CONCLuSion}

The factors that influence the interest of rural youth in farming are prestige factors, that are having the same honor as other jobs in terms of profession and honor which are the same as other jobs in the selection of a prospective spouse. The second factor that influence the interest of rural youth in farming is the future guarantee, that are life insurance and future guarantee. The third factor that affects is the parental land area. An interesting finding is that narrower the land area, the greater the interest of rural youth in farming. This is in line with the condition of the local culture, the hereditary inheritance of the land which is getting smaller and smaller. While the privilege factor, parental encouragement, education level, education suitability, commodity value and income do not significantly influence the interest of rural youth to farm.

\section{REFERENCES}

[1] Andersson Djurfeldt, A. et al. (2019) 'Yearning to farm - Youth, agricultural intensification and land in Mkushi, Zambia', Journal of Rural Studies. Elsevier, 71(August), pp. 85-93. doi: 10.1016/j.jrurstud. 2019.08.010

[2] Arslan, A. et al. (2020) 'Youth Inclusion in Rural Transformation', Journal of Development Studies. Routledge, 00(00), pp. 1-7. doi: 10.1080/00220388.2020.1808199.

[3] Auta, S. J., Abdullahi, Y. M. and Nasiru, M. (2010) 'Rural Youths' participation in agriculture: Prospects, challenges and the implications for policy in Nigeria', Journal of Agricultural Education and Extension, 16(3), pp. 297-307. doi: 10.1080/1389224X.2010.489769.

[4] Betcherman, G. and Khan, T. (2018) 'Jobs for Africa's expanding youth cohort: a stocktaking of employment prospects and policy interventions', IZA Journal of Development and Migration. IZA Journal of Development and Migration, 8(1). doi: 10.1186/s40176-018-0121-y.

[5] Bezu, S. and Holden, S. (2014) 'Are rural youth in ethiopia abandoning agriculture?', World Development. Elsevier Ltd, 64, pp. 259-272. doi: 10.1016/j.worlddev.2014.06.013.

[6] Che, F. N., Strang, K. D. and Vajjhala, N. R. (2020) 'Voice of farmers in the agriculture crisis in NorthEast Nigeria: Focus group insights from extension workers', International Journal of Development Issues, 19(1), pp. 43-61. doi: 10.1108/IJDI-08-2019-0136.

[7] Cheteni, P. (2016) 'Youth Participation in Agriculture in the Nkonkobe District Municipality, South Africa', Journal of Human Ecology, 55(3), pp. 207-213. doi: 10.1080/09709274.2016.11907025.

[8] Ibrahim, J. T. and Mazwan, M. Z. (2020) 'Structural Transformation of Agricultural Sector in East Java Indonesia', International Journal of Economics and Management Studies (SSRG-IJEMS), 7(3), pp. 1-7. 
[9] Inegbedion, G. and Islam, M. M. (2020) 'Youth motivations to study agriculture in tertiary institutions', Journal of Agricultural Education and Extension. Taylor \& Francis, 26(5), pp. 497-512. doi: 10.1080/13 89224X.2020.1773285.

[10] Katie D. Ricketts, C. G. T. and M. I. G. (2019) 'Journal of Agribusiness in Developing and Emerging Economies Article information ':, Smallholder farmer perceptions of risk and benefits across three cocoa chains in Ghana, 8(2), pp. 1-40. Available at: https://doi.org/10.1108/JADEE-03-2018-0038.

[11] Khatir, A. and Rezaei-Moghaddam, K. (2014) 'Evidence from predictors of rural youth's migration intentions in agricultural communities: the Fars province, Iran', Migration and Development. Routledge, 3(2), pp. 219-238. doi: 10.1080/21632324.2014.926612.

[12] Kidido, J. K. and Bugri, J. T. (2020) 'Youth Access to Agricultural Land from Peri-urban and Rural Perspective: A Study of Techiman Traditional Area in Ghana', Journal of Land and Rural Studies, 8(1), pp. 37-56. doi: 10.1177/2321024919883145.

[13] Kidido, J. K., Bugri, J. T. and Kasanga, R. K. (2017) 'Youth Agricultural Land Access Dimensions and Emerging Challenges Under the Customary Tenure System in Ghana', Journal of Land and Rural Studies, 5(2), pp. 140-163. doi: 10.1177/2321024917700940.

[14] Kumar, A. (2010) 'From the Field to the Factory', Social Change, 40(3), pp. 303-317. doi: 10.1177/ 004908571004000304.

[15] Kvartiuk, V. et al. (2020) 'A Brain Drain in Russian Agriculture? Migration Sentiments among Skilled Russian Rural Youth', Europe - Asia Studies, 72(8), pp. 1352-1377. doi: 10.1080/09668136.20 20.1730305 .

[16] Larsen, A. F. and Lilleør, H. B. (2014) 'Beyond the Field: The Impact of Farmer Field Schools on Food Security and Poverty Alleviation', World Development. Elsevier Ltd, 64, pp. 843-859. doi: 10.1016/j.worlddev.2014.07.003.

[17] Leonard, O., Okoro, O. E. U. and Imo, I. G. (2020) 'Strategic government policies on agricultural financing in African emerging markets', Agricultural Finance Review. Emerald Publishing Limited, 80(4), pp. 563-588. doi: 10.1108/AFR-01-2020-0013.

[18] McCullagh, M. C., Yang, J. J. and Cohen, M. A. (2020) 'Community-based program to increase use of hearing conservation practices among farm and rural youth: A cluster randomized trial of effectiveness', BMC Public Health. BMC Public Health, 20(1), pp. 1-10. doi: 10.1186/s12889-020-08972-3.

[19] Metelerkamp, L., Drimie, S. and Biggs, R. (2019) 'We're ready, the system's not-youth perspectives on agricultural careers in South Africa’, Agrekon. Taylor \& Francis, 58(2), pp. 154-179. doi: 10.1080/0303 1853.2018.1564680.

[20] Onemolease, E. A. and Alakpa, S. O. (2009) 'Determinants of Adoption Decisions of Rural Youths in the Niger Delta Region of Nigeria', Journal of Social Sciences, 20(1), pp. 61-66. doi: 10.1080/0971892 3.2009.11892722.

[21] Ripoll, S. et al. (2017) 'Rural transformation, cereals and youth in Africa: What role for international agricultural research?', Outlook on Agriculture, 46(3), pp. 168-177. doi: 10.1177/0030727017724669.

[22] Sharma, A. (2007) 'The changing agricultural demography of india: Evidence from a rural youth perception survey', International Journal of Rural Management, 3(1), pp. 27-41. doi: 10.1177/097 300520700300102.

[23] Swarts, M. B. and Aliber, M. (2013) "The "youth and agriculture" problem: implications for rangeland development', African Journal of Range and Forage Science, 30(1-2), pp. 23-27. doi: 10.2989/10220119.2013.778902.

[24] Webster, N. and Ganpat, W. (2014) 'St Vincent Youth and Careers in Agriculture', Journal of Agricultural Education and Extension, 20(1), pp. 49-64. doi: 10.1080/1389224X.2013.775952.

[25] Yeboah, T. et al. (2020) 'Hard work and hazard: Young people and agricultural commercialisation in Africa', Journal of Rural Studies. Elsevier, 76(September 2019), pp. 142-151. doi: 10.1016/j.jrurstud. 2020.04.027.

Citation: Jabal Tarik Ibrahim, et.al. " Factors Affecting Rural Youth Interest in Agriculture in Probolinggo District Indonesia” International Journal of Humanities Social Sciences and Education (IJHSSE), vol 8, no. 1, 2021, pp. 59-66. doi: https://doi.org/10.20431/2349-0381.0801008.

Copyright: (C) 2021 Authors. This is an open-access article distributed under the terms of the Creative Commons Attribution License, which permits unrestricted use, distribution, and reproduction in any medium, provided the original author and source are credited. 